\title{
Occurrence and Distribution of Tomato Leaf Curl Virus Disease in Marathwada Region of Maharashtra State
}

\author{
P.M. Khandare, D.N. Dhutraj and C.V. Ambadkar* \\ Department of Plant Pathology, College of Agriculture, Parbhani, Vasantrao Naik \\ Marathwada Krishi Vidyapeeth, Parbhani- 431402 (MS), India \\ *Corresponding author
}

Key w o r d s
Field survey,
Tomato, Leaf curl,
Occurrence,
Distribution

\section{Introduction}

Tomato (Lycopersicon esculentum Mill.) is an importance and most widely grown vegetable crop of both tropics and sub tropics of the world, belonging to the family Solanaceae and ranks second among vegetables. The major tomato producing states in India are Maharashtra, Bihar, Karnataka, Uttar Pradesh,
Orissa, Andhra Pradesh, Madhya Pradesh and Assam. Tomato cultivation has becomes increasingly popular in India because of its varied climatic condition and high nutritive value. Biotic and abiotic factors are the major constraints in the production and productivity of tomato. More than 200 diseases have been reported on tomato, out of which 40 are caused by viruses (Martelli and Quacquarelli, 
1982; Lukyanenko, 1991). Among viral diseases tomato leaf curl virus (ToLCV) belonging to family Geminiviridae and genus Begomovirus virus is considered most devastating (Kalloo, 1991). In India occurrence of leaf curl virus disease was first observed in the northern plains by $\mathrm{Pal}$ and Tandon (1937) (Yadav et al., 2014). Tomato leaf curl virus (ToLCV) is one of the most devastating in India. First report on the natural occurrence of tobacco leaf curl virus (ToLCV) was observed on tomato in India by (Pruthi and Samuel 1939) and it was first reported in northern India by Vasudeva and Samraj (1948).

ToLCV is transmitted by whitefly (Bemisia tabaci Genn.) in a persistent and circulative manner as well as by grafting and not through seed, soil, sap or nematode (Uchibori et al., 2013).

Most of the tomato hybrids currently under cultivation in India have shown various degrees of susceptibility to the disease. All the cultivatable varieties of tomato genotype were susceptible for disease however cultivation of resistant variety was considered to be cheap and ecologically safe.

Keeping in view, the economic importance of the tomato crop and yield losses produced by tomato leaf curl disease in tomato, present studies were emphasized on study of occurrence and distribution pattern of tomato leaf curl virus disease in Marathwada region of Maharashtra state.

\section{Materials and Methods}

\section{Field Survey}

To know the occurrence and distribution of the leaf curl virus disease of tomato, a roving survey was conducted in tomato growing areas during Rabi and Summer seasons of 2017-18 and 2018-19 in the eight districts of Marathwada region to asses leaf curl virus disease incidence. Tomato growing pockets were identified from the records available at the office of Sub-Divisional Agriculture Officer of each district in Marathwada region. For this purpose the tomato crop grown on more than 0.4 ha area was selected. To assess the incidence of this disease, ten sampling units of ten squares meters were selected randomly. The incidence of leaf curl virus disease of tomato was recorded along with healthy plants in each sampling unit. Per cent disease incidence was calculated using the following formula.

Per cent disease incidence

Number of plants infected

= --------------------------------- $\mathrm{x} 100$

Total number of plants observed

The overall disease incidence was recorded based on visual symptoms.

\section{Results and Discussion}

The survey of tomato crop from eight districts (Aurangabad, Jalna, Parbhani, Beed, Hingoli, Latur and Osmanabad) of Marathwada region of the Maharashtra state was carried out during Rabi 2017-18 and Summer 2018-19 seasons to record seasonal per cent disease incidence. The results obtained are presented herein.

\section{District wise seasonal incidence of tomato leaf curl virus disease}

Results (Table 1) revealed that during Rabi 2017-18 leaf curl average disease incidence in the eight district surveyed was ranged from 32.58 (Aurangabad) to 44.80 (Hingoli). However the tomato crops grown in the district of Hingoli were found to be affected with maximum average disease incidence (44.80\%). This was followed by district viz., 
Latur (40.31\%), Beed (39.79\%), Parbhani (39.24\%), Osmanabad (38.61\%), Nanded (37.33\%), Jalna (33.56\%) and Aurangabad $(32.58 \%)$, with average disease incidence respectively.

During Summer, 2018-19 leaf curl disease incidence (Table 2) were found to be comparatively maximum to that of during Summer 2017-18. Average leaf curl disease incidence in eight district surveyed during Summer 2018-19 were ranged from 42.67 (Aurangabad) to 52.75 (Hingoli). However, the tomato crops grown in the district of Hingoli were found to be affected more severely with maximum average disease incidence $(52.75 \%)$. This was followed by district viz., Parbhani (50.67\%), Nanded (49.41\%), Latur (48.48\%), Beed (46.58\%), Osmanabad (46.50\%), Jalna (45.92\%) and Aurangabad (42.67\%), with average disease incidence respectively.

Overall average leaf curl virus disease incidence was found to be maximum in Summer grown tomato crop, as compared to that of Rabi crop (Table 3). During Summer 2017-18 season, overall average leaf curl incidence was 46.54 Per cent, and during Rabi 2017-18 overall average leaf curl incidence was 38.27 per cent.

\section{Variety wise seasonal incidence of tomato leaf curl virus disease}

In the eight district of the Marathwada region surveyed for recording leaf curl disease incidence, a wide range of tomato cultivars / varieties, F1 hybrids and local varieties were grown by the farmers. The results obtained on leaf curl virus disease incidence are presented in the Table 4. During Rabi 2017-18 the average leaf curl virus disease incidence on the tomato cultivars grown was ranged from
28.15 (Abhilasha) to 45.19 (Local) per cent. Tomato cultivars / verities, grown during Rabi season were found to be less affected by leaf curl virus disease as compared to that of gown during Summer season. However, tomato local cultivar was found to be affected more with maximum average disease incidence $(45.19 \%)$. This was followed by the tomato cultivars Pusa Ruby (43.51\%), Us440 (51.75\%), Arka Vikas (38.79\%), Vishwanath $(33.33 \%)$ and Vaibhav (32.10\%) with average disease incidence respectively. The tomato cultivars grown Vaishali, PKM-1 and Laxmi were found comparatively least affected by the disease.

During Summer 2018-19 the average leaf curl virus disease incidence on the tomato cultivars grown were ranged from 34.00 (Vishwanath) to 57.25 (Local) per cent. However, tomato local cultivars was found to be affected more with maximum average disease incidence $(57.25 \%)$ than other tomato cultivars.

Pusa Ruby was with second maximum average disease incidence $(53.95 \%)$ and Us440 (51.57\%) with third maximum average disease incidence followed by Laxmi $(50.00 \%)$ and PKM (48.07\%). Rest of the tomato cultivars exhibited average disease incidence in the range of 47.16 to 45.72 per cent. Tomato cultivars viz., Vaishali and Arka Vikas were found to suffer less with the disease, which recorded minimum average disease incidence of Abhilasha (41.50\%) and Vaibhav (36.02\%), respectively.

These results of the present studies on occurrence and distribution of tomato leaf curl virus are similar to those reported earlier by several workers on tomato crops. Ranbir Singh et al., (2016) reported that the ToLCD percentage of disease incidence was ranged from 29.60-47.20 per cent (Fig. 1 and 2). 
Table.1 Incidence of tomato leaf curl virus disease in the district of Marathwada during Rabi 2017-2018

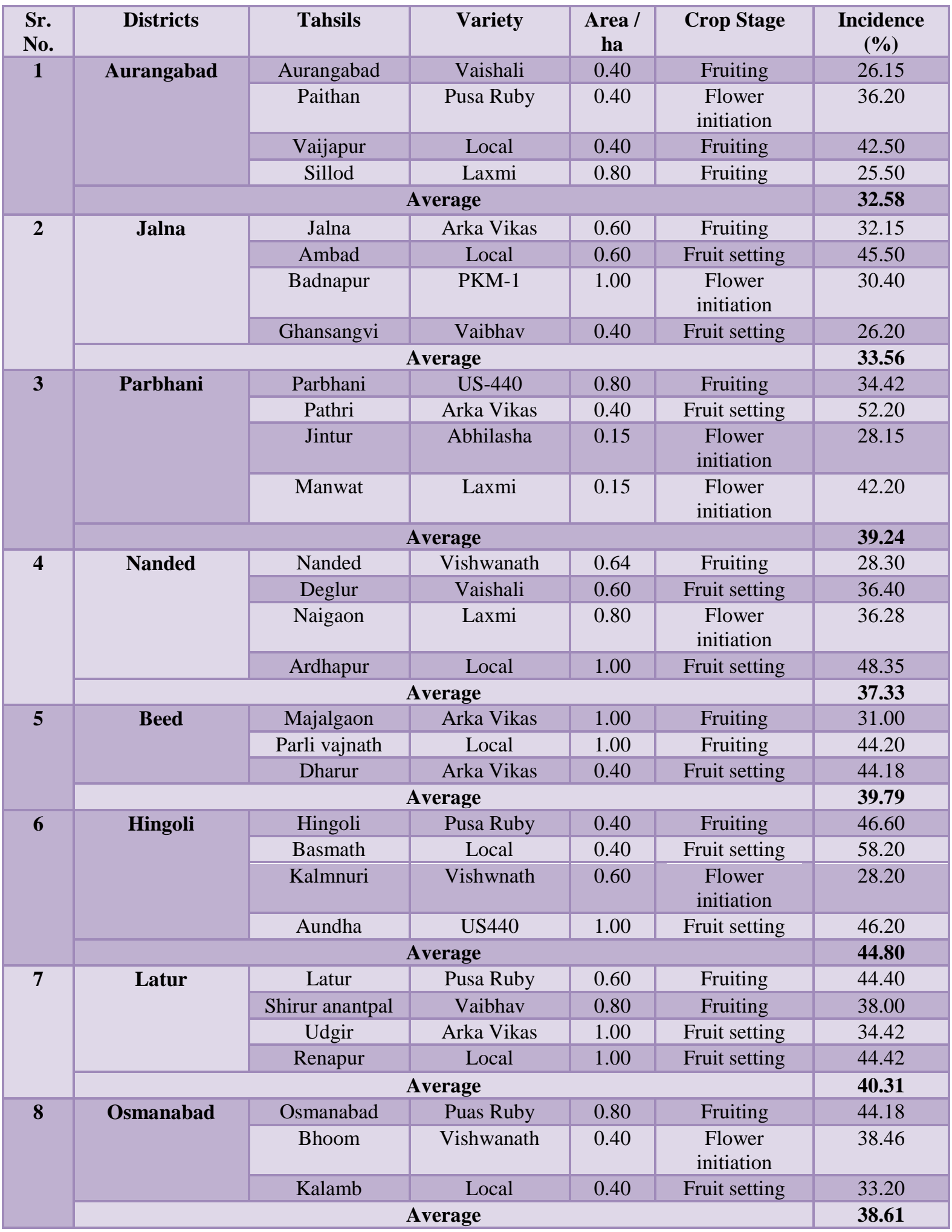


Table.2 Incidence of tomato leaf curl virus disease in the district of Marathwada during Summer, 2018-19

\begin{tabular}{|c|c|c|c|c|c|c|}
\hline $\begin{array}{l}\text { Sr. } \\
\text { No. }\end{array}$ & Districts & Tahsils & Variety & $\begin{array}{c}\text { Area / } \\
\text { ha }\end{array}$ & Crop Stage & $\begin{array}{c}\text { Incidence } \\
(\%)\end{array}$ \\
\hline \multirow[t]{5}{*}{1} & \multirow[t]{4}{*}{ Aurangabad } & Aurangabad & Vaishali & 1.50 & Fruiting & 44.00 \\
\hline & & Paithan & Local & 0.10 & Fruit setting & 54.00 \\
\hline & & Vaijapur & Pusa Ruby & 0.40 & Flower initiation & 42.20 \\
\hline & & Sillod & Vaibhav & 1.00 & Flower initiation & 30.50 \\
\hline & \multicolumn{5}{|c|}{ Average } & 42.67 \\
\hline \multirow[t]{5}{*}{2} & \multirow[t]{4}{*}{ Jalna } & Jalna & Arka Vikas & 0.40 & Fruiting & 45.00 \\
\hline & & Badnapur & Vaibhav & 0.48 & Fruit setting & 32.50 \\
\hline & & Ambad & PKM-1 & 0.60 & Flower initiation & 50.00 \\
\hline & & Ghansavgi & Local & 0.40 & Flower initiation & 56.20 \\
\hline & \multicolumn{5}{|c|}{ Average } & 45.92 \\
\hline \multirow[t]{5}{*}{3} & \multirow[t]{4}{*}{ Parbhani } & Parbhani & Us440 & 0.10 & Fruiting & 45.10 \\
\hline & & Jintur & Abhilasha & 0.40 & Fruit setting & 41.50 \\
\hline & & Manwat & Pusa Ruby & 0.15 & Flower initiation & 64.10 \\
\hline & & Gangakhed & Arka vikas & 1.00 & Flower initiation & 52.00 \\
\hline & \multicolumn{5}{|c|}{ Average } & 50.67 \\
\hline \multirow[t]{5}{*}{4} & \multirow[t]{4}{*}{ Nanded } & Nanded & Arka Vikas & 0.52 & Fruiting & 44.00 \\
\hline & & Ardhapur & Vaishali & 0.56 & Fruit setting & 45.50 \\
\hline & & Hadgaon & Local & 0.40 & Flower initiation & 62.00 \\
\hline & & Loha & PKM-1 & 1.00 & Fruit setting & 46.15 \\
\hline & \multicolumn{5}{|c|}{ Average } & 49.41 \\
\hline \multirow[t]{4}{*}{5} & \multirow[t]{3}{*}{ Beed } & Beed & Arka Vikas & 0.40 & Fruiting & 45.10 \\
\hline & & Ambajogai & Local & 0.15 & Fruiting & 52.15 \\
\hline & & Kaji & Arka Vikas & 0.10 & Fruit setting & 42.50 \\
\hline & \multicolumn{5}{|c|}{ Average } & 46.58 \\
\hline \multirow[t]{5}{*}{6} & \multirow[t]{4}{*}{ Hingoli } & Hingoli & Vaibhav & 0.40 & Fruiting & 36.10 \\
\hline & & Sengaon & Laxmi & 0.40 & Fruiting & 51.50 \\
\hline & & Basmath & Local & 0.40 & Fruit setting & 65.00 \\
\hline & & Aundha & Us440 & 0.40 & Fruit setting & 58.40 \\
\hline & \multicolumn{5}{|c|}{ Average } & 52.75 \\
\hline \multirow[t]{5}{*}{7} & \multirow[t]{4}{*}{ Latur } & Latur & Pusa Ruby & 0.50 & Fruiting & 52.50 \\
\hline & & Ahmadpur & Vaibhav & 0.40 & Fruiting & 45.00 \\
\hline & & Chakur & Vaishali & 0.40 & Flower initiation & 42.00 \\
\hline & & Udgir & Local & 1.00 & Fruiting & 54.20 \\
\hline & \multicolumn{5}{|c|}{ Average } & 48.48 \\
\hline \multirow[t]{4}{*}{8} & \multirow[t]{3}{*}{ Osmanabad } & Bhoom & Pusa Ruby & 0.10 & Fruiting stage & 57.00 \\
\hline & & Kalamb & Laxmi & 0.40 & Fruit setting & 48.50 \\
\hline & & Paranda & Vishwanath & 0.60 & Flower initiation & 34.00 \\
\hline & \multicolumn{5}{|c|}{ Average } & 46.50 \\
\hline
\end{tabular}


Table.3 District wise incidence of tomato leaf curl virus disease in Marathwada during Rabi 2017-18 and Summer 2018-19

\begin{tabular}{|c|c|c|c|}
\hline \multirow{2}{*}{$\begin{array}{c}\text { Sr. } \\
\text { No. }\end{array}$} & \multirow{2}{*}{ District } & \multicolumn{2}{|c|}{ Av. Incidence (\%) } \\
\hline $\mathbf{1}$ & Aurangabad & 32.58 & Summer \\
\hline $\mathbf{2}$ & Jalna & 33.56 & 42.67 \\
\hline $\mathbf{3}$ & Parbhani & 39.24 & 45.92 \\
\hline $\mathbf{4}$ & Nanded & 37.33 & 50.67 \\
\hline $\mathbf{5}$ & Beed & 39.79 & 49.41 \\
\hline $\mathbf{6}$ & Hingoli & 44.80 & 46.58 \\
\hline $\mathbf{7}$ & Latur & 40.31 & 52.57 \\
\hline $\mathbf{8}$ & Osmanabad & 38.61 & 48.48 \\
\hline & Overall Av. (\%) & $\mathbf{3 8 . 2 7}$ & 46.50 \\
\hline
\end{tabular}

Table.4 Variety wise incidence of tomato leaf curl virus disease in the Marathwada region during Rabi 2017-18 and Summer 2018-19.

\begin{tabular}{|c|c|c|c|}
\hline \multirow{2}{*}{ Sr. No. } & Variety & \multicolumn{2}{|c|}{ Incidence (\%) } \\
\cline { 3 - 4 } & Arka Vikas & 38.79 & 45.72 \\
\hline $\mathbf{1}$ & Vaibhav & 32.10 & 36.02 \\
\hline $\mathbf{3}$ & Vaishali & 31.27 & 47.16 \\
\hline $\mathbf{4}$ & Pusa Ruby & 43.51 & 53.95 \\
\hline $\mathbf{5}$ & PKM-1 & 30.40 & 48.07 \\
\hline $\mathbf{6}$ & Abhilasha & 28.15 & 41.50 \\
\hline $\mathbf{7}$ & Laxmi & 32.06 & 50.00 \\
\hline $\mathbf{8}$ & Us440 & 40.31 & 51.75 \\
\hline $\mathbf{9}$ & Vishwanath & 33.33 & 34.00 \\
\hline $\mathbf{1 0}$ & Local & 45.19 & 57.25 \\
\hline \multicolumn{2}{|c|}{ Overall average (\%) } & $\mathbf{3 5 . 5 1}$ & $\mathbf{4 6 . 5 4}$ \\
\hline
\end{tabular}


Fig.1 District-wise incidences of tomato leaf curl virus disease in Marathwada region of Maharashtra during Rabi, 2017-18 and Summer, 2018-19

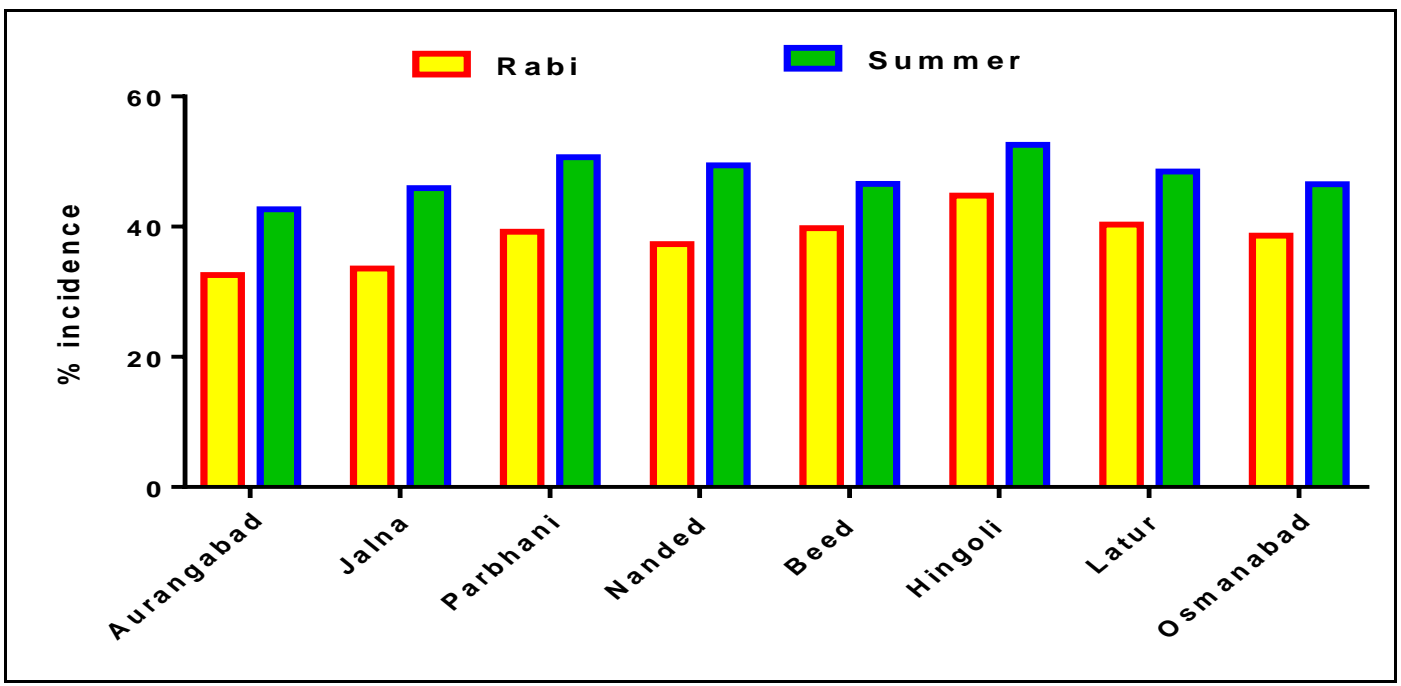

Fig.2 Variety wise incidence of tomato leaf curl virus disease in Marathwada region of Maharashtra during Rabi, 2017-18 and Summer, 2018-19

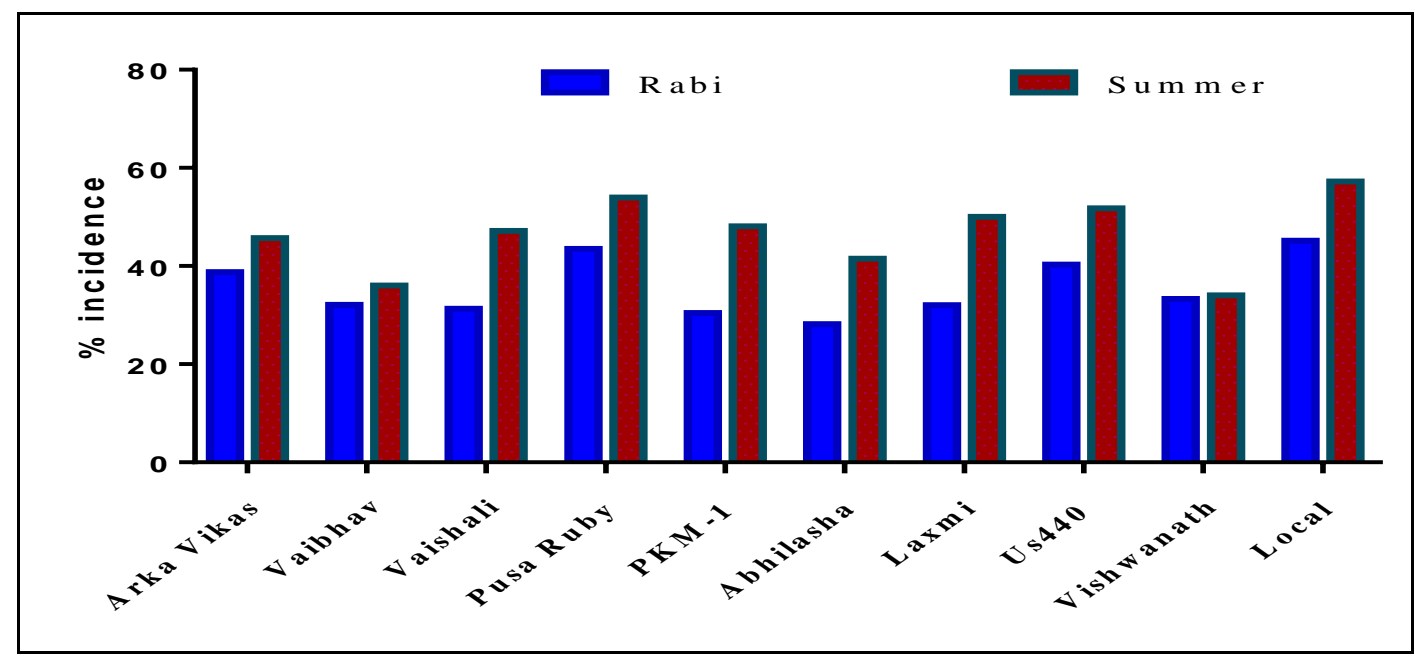

The overall incidence of the disease ranged from 20.0-37.6 per cent in Jammu district while in Kathua and Udhampur districts, the incidence of the disease was $33.6-44.8$ and 25.6-33.6 per cent respectively, whereas, Koshale and Khare (2018) observed first appearance of leaf curl in the first fortnight of August in 2015 and 2017, and in the second fortnight of August in 2016 and progressed up to the first fortnight of November. Initially the occurrence of the disease started with very low per cent disease incidence $(1.00,3.70$, and 2.66) and PDI (0.24, 1.49 and 1.14) which increased with increase in age of the plant and reached maximum in first fortnight of November $(68.48,49.58 ; 62.36,45.56 ; 69.64$, 51.30).

The ToLCD was present in almost all fields of Belgaum, Dharwad and Haveri districts 
surveyed with the disease incidence ranged from 4-100 percent in Rabi and was in severe form ranging from 60 to 100 per cent during Summer has been reported by Reddy (2006) and Reddy et al., (2011). The ToLCD with 10.8 to 91.3 percent disease incidence in major tomato growing districts of Karnataka with highest disease incidence of 70.81 per cent in Kolar and least incidence of 21.00 per cent in Ramanagara district has been reported by Ehsanullah, (2014). Rathnamma and Patil (2018) surveyed tomato leaf curl disease (ToLCD) incidence and severity during 20152016 ranging from 5.0 to 86.6 per cent and 2.0 to 45.2 per cent, respectively. The highest ToLCD incidence recorded in Haveri district $(86.6 \%)$ and severity recorded in Yadgir (45.2 $\%)$. The least ToLCD incidence $(5.0 \%)$ and severity $(2.0 \%)$ was recorded in Dharwad district.

Based on the above data it can be concluded that tomato leaf curl virus disease of tomato is common occurrence and widely distributed in all the eight district of Marathwada. However, it was more intense / severe during Summer than Rabi season and all tomato cultivars/ hybrids presently under cultivation are prone to the disease.

\section{References}

Anonymous. 2013-14. Annual report, Indira Gandhi Krishi Vishwavidyalaya, Raipur (Chhattisgarh).

Ehsanullah. 2014. Survey for prevalence of Tomato leaf curl virus (ToLCV) strains in Karnataka and identification of resistance source. M. Sc. Thesis, University of Agricultural Sciences GKVK, Bangalore.

Kalloo.G. 1991. Genetic improvement of tomato. Springer Verlag, Berlin Heidelberg. http://dx.doi.org/10.1007/978-3-64284275-7.
KN Koshale and CP Khare. 2018. Seasonal occurrence of prevalent diseases of tomato under field conditions. IJCS 2018; 6 (5): 2002-2006.

Lukyanenko, A. N. 1991. Disease resistance in tomato. Springer Verlag, Berlin Heidelberg.

Martelli, G. P. and Quacquarelli, A. 1982. The present status of tomato and pepper viruses. Acta Horti. 127: 39- 64.

Pal, B. P. and Tandon, R. K. 1937. Types of tobacco leaf curl in Northern India. Indian J. Agric. Sci. 7:363-393.

Pruthi, H. S. and Samuel, C. K. 1939. Entomological investigation on the leaf curl disease of tobacco in Northern India- III. The transmission of leaf curl by whitefly, Bemisiagossypipedra, to tobacco, sunhemp and a new alternate host of the leaf curl virus. Indian Journal of Agricultural Sciences, 9: 223-275.

Ranbir Singh, V. K. Razdan and Manika Sharma. 2016. Prevalence and Detection of tomato leaf curl virus from Low Altitude Subtropical Areas of Jammu and Kashmir. Int. J. Curr. Microbiol. App. Sci. 5 (11): 768-773. doi:

http://dx.doi.org/10.20546/ijcmas.2016 .511 .088

Rathnamma and Patil, M. S. 2018. Survey for tomato leaf curl virus disease incidence and severity in different tomato growing areas of Northern Karnataka, India. Int. J. Curr. Microbiol. App. Sci. 7(04): 2793-2800.

Reddy, A. B. 2006. Molecular Characterization, Epidemiology and Management of tomato leaf curl virus (ToLCV) in Northern Karnataka. Ph. D. Thesis, University of Agricultural Sciences, Dharwad.

Reddy, B. A., Patti, M. S., Reddy, K. M. and Venkataravanappa,V., 2011. Detection and diagnosis of tomato leaf curl virus 
infecting tomato in Northern Karnataka. African Journal of Agricultural Research, 6 (5): 10511057.

Saikia, A. K. and Muniyappa, V., 1989. Epidemiology and control of tomato leaf curl virus in Southern India. Tropical Agriculture, 66:350-354.

Uchibori, M., A. Hirata, M. Suzuki and M. Ugaki,, 2013. Tomato yellow leaf curl virus accumulates in vesicle- like structures in descending and ascending midgut epithelial cells of the vector whitefly, Bemisia tabaci, but not in those of non-vector whitefly Trialeurodes vaporariorum. J. Gen. Plant Pathol., 79:115-122.

Vasudeva, R. S. and Sam Raj, 1948. Leaf curl disease of tomato. Phytopathology, 18:364-369.

Yadav, K., Sadhankumar, P. G., Nirmaladevi, S. Mathew, S. K., George, T. E. and Krishnan, S. 2014. Vegetable Science, 41 (1): 63-65.

\section{How to cite this article:}

Khandare, P.M., D.N. Dhutraj and Ambadkar, C.V. 2019. Occurrence and Distribution of Tomato Leaf Curl Virus Disease in Marathwada Region of Maharashtra State. Int.J.Curr.Microbiol.App.Sci. 8(11): 814-822. doi: https://doi.org/10.20546/ijcmas.2019.811.096 